\title{
Productive and biological features of breeding Irish pigs of various genotypes in Western Siberia
}

\author{
Svetlana Burtseva*, Lyubov Khripunova, Alexander Yashkin, Lyudmila Pautova and Sergey Chebakov.
}

Altai State Agricultural University, 98, Prospekt Krasnoarmeyskiy, Barnaul, 656049, Russia

\begin{abstract}
The present work studies the productive and biological characteristics of breeding Irish pigs of different genotypes in the conditions of Western Siberia. Pure-bred selection of Large White pigs (WP) was used in the first control group and intra-breed selection of Landrace pigs (LP) was used in the second control group. The following patterns of interbreeding were used in the experimental groups: $\odot \mathrm{WP} \times{ }^{\lambda} \mathrm{LP}$ (third group), $\$ \mathrm{LP} \times{ }^{\lambda} \mathrm{WP}$ (fourth group). In terms of reproductive qualities, the best combination should be considered the selection of $+\mathrm{WP} \times \delta^{\Uparrow} \mathrm{LP}$, in which $8.1 \%(\mathrm{p}<0.05)$ more piglets were obtained at 30 days, with a $10.0 \%(p<0.05)$ higher weight of the nest at 30 days and $3.6 \%(p<0.05)$ greater safety than in the first control group. The combination of breeds according to the क $\mathrm{LP} \times{ }^{-} \mathrm{WP}$ scheme contributed to an increase in the average daily $13.7 \%(\mathrm{p}<0.05)$ gain in live weight of the resulting offspring. At the age of 4 months, piglets of the LP $\times$ WP genotype had a $10.9 \%(\mathrm{p}<0.05)$ higher content of total protein in the blood serum than in animals of the Large White breed. The muscle tissue of Large White pigs was characterized by a $5.2 \%(\mathrm{p}<0.05)$ higher moisture binding capacity in relation to Landrace pigs. The melting point of fatty tissue was lower in Large White pigs by $14.3 \%(\mathrm{p}<0.05)$. The fatty tissue of LP $\times$ WP hybrids has a $10.0 \%$ higher melting point $(\mathrm{p}<0.05)$ in contrast to Large White pigs.
\end{abstract}

\section{Introduction}

The productive qualities and pig meat quality depend on many factors including feeding and genotype [1].

The health and performance of breeding pigs are key factors depending on heritability and animal genetics. The Landrace pig breed is a relatively modern breed and one of the most widespread breeds in the world. It has high lean meat and is used for high quality pork [2].

The use of Yorkshire pigs results in high quality meat production. Pigs known as the source breed are common in the United States and Canada and are muscular, high in lean meat and low in fat [3].

Taking into account the population growth and the level of economic development, a twofold increase in the consumption of pork is predicted. The production possibilities of pork in developed countries are very limited [4].

\section{Problem statement}

As a result of two- and three-breed crossing of pigs, a stable effect of heterosis is manifested in terms of the main economically useful traits, which is primarily expressed in an increase in the quality of meat. It is important to remember that the substantiation of the effectiveness of one or another system of crossing and hybridization and the competent choice of the optimal option regarding the regional specifics of the industry, can be based only on extensive experimental data $[5,6]$.
Interbreeding and crossbreeding enables to improve the meat qualities of pigs while maintaining the good technological properties of the meat. However, in some cases, no significant differences are found in terms of meat quality between purebred and crossbred animals [7].

Interest in breeding Irish animals has been driven by the obvious advances in Irish pig production in recent years concerning animal fertility and obtaining valuable lean pork. From 2000 to 2010 fertility per a breeding pig increased in the country from 21.6 to 24.1 per year, the mortality of piglets before weaning from a breeding pig was the lowest in Europe and amounted to $10.7 \%$ [8].

\section{Research Questions}

The effect of heterosis is most clearly manifested in interbreeding and hybridization, which are undoubtedly the main strategies aimed to improve the reproductive qualities of breeding pigs. A higher level of reproductive qualities development is due to the genetic heterogeneity of gametes, which determines the best survival of the offspring in the prenatal and postnatal periods. Usually, interbreeding results in an increase in productivity in hybrid pigs for a number of the most valuable traits.

Our research covers a wide range of issues and they are as follows:

1 Studying the reproductive qualities of Irish breeding pigs.

2 Characteristics of the fattening qualities of young pigs of different origins.

\footnotetext{
* Corresponding author: sve-burceva@yandex.ru
} 
3 Analysis of blood parameters of young pigs.

4 Research of technological properties of muscle and fatty tissue of pigs of Irish selection.

The aim of this work is to study the productive qualities and biological characteristics of Irish breeding pigs of different genotypes in the conditions of Western Siberia.

\section{Research Methods}

\subsection{Research objects, scheme of experiment}

According to the experimental scheme (Table 1), the basis for the scientific experiment was the pig-breeding enterprise OOO “Altaymyasoprom” (Altai Krai, Russia).

Table 1. Organization of scientific and economic experiment.

\begin{tabular}{|c|c|}
\hline Group & Combination of breeds $\$ \times \sigma^{\circ}$ \\
\hline 1 control & $\mathrm{WP}^{1} \times \mathrm{WP}$ \\
\hline 2 control & $\mathrm{LP}^{2} \times \mathrm{LP}$ \\
\hline 3 experimental & $\mathrm{WP} \times \mathrm{LP}$ \\
\hline 4 experimental & $\mathrm{LP} \times \mathrm{WP}$ \\
\hline
\end{tabular}

$1 \mathrm{WP}$ is Large White pigs, $2 \mathrm{LP}$ is Landrace pigs

The objects of research were sows and boars of Large White breed and Landrace breed of Irish selection, as well as young pigs obtained as a result of crossing these breeds of pigs. In the first control ( \&WP $\times$ क्WP) and the second control ( \&LP $\times$ LP) groups, purebred breeding of pigs of Irish selection was used. In the third experimental group, Large White sows were inseminated by Landrace boars. In the fourth experimental one, LP sows and WP boars were interbred.

\subsection{Reproductive qualities of sows}

Reproductive qualities of sows selected by the analog pair method were assessed according to the results of the third farrowing. Piglets were weaned from sows at the $28^{\text {th }}$ day. As a result of the experiment, young animals of different genotypes of Irish selection were evaluated on the control breeding. The conditions of feeding and keeping the animals in the experiment corresponded to the technology adopted at the enterprise and were the same.

\subsection{Pig blood indicators}

Blood was taken from young pigs at the age of 4 and 6 months for determining biochemical parameters. Blood tests were carried out at the Altai State Agrarian University on a BioChem SA biochemical analyzer. The total protein content in blood serum was determined by the biuret method, calcium - by the o-cresolphthalein method, phosphorus - by the colorimetric method.

\subsection{Pig muscle and fatty tissue quality}

The post-slaughter indicators of the experimental young animals were assessed when the animals reached $100 \mathrm{~kg}$ of weight. At the control slaughter, samples of muscle and fatty tissue were taken for laboratory studies. Technological indicators of the meat quality, in particular, the moisture-binding capacity of muscle tissue was determined by the press method (Grau and Hamm), the melting point of fatty tissue was estimated by the capillary method, the moisture content in meat was studied by drying the samples in a drying oven to constant weight.

\subsection{Statistical data processing}

The experimental data were statistically processed by the biometric method in the MS Office software module. The statistical significance of the differences in the indices of the experimental groups was determined by the Student's test.

\section{Findings}

\subsection{Reproductive qualities of sows}

The results of studying the reproductive qualities of Irish selection sows are shown in Table 2.

Table 2. Reproductive qualities of sows $(n=12)$.

\begin{tabular}{|c|c|c|c|c|c|}
\hline Group & $\begin{array}{c}\text { Total prolificacy, } \\
\text { heads } \pm \text { SD }\end{array}$ & $\begin{array}{c}\text { Prolificacy (live), } \\
\text { heads } \pm \text { SD }\end{array}$ & $\begin{array}{c}\text { The number of piglets in the } \\
\text { nest in 30 days, heads } \mathbf{\text { SD }}\end{array}$ & $\begin{array}{c}\text { Nest weight in 30 } \\
\text { days, kg } \pm \text { SD }\end{array}$ & $\begin{array}{c}\text { Livability, \% } \\
\mathbf{\pm} \text { SD }\end{array}$ \\
\hline 1 & $12.8 \pm 0.36$ & $11.8 \pm 0.36$ & $11.1 \pm 0.33$ & $87.3 \pm 3.02$ & $93.8 \pm 1.14$ \\
\hline 2 & $11.9 \pm 0.42$ & $11.7 \pm 0.43$ & $11.3 \pm 0.32$ & $91.8 \pm 2.07$ & $96.8 \pm 1.51$ \\
\hline 3 & $13.3 \pm 0.23^{2^{* *}}$ & $12.3 \pm 0.27$ & $12.0 \pm 0.26^{1^{*}}$ & $96.0 \pm 1.96^{1^{*}}$ & $97.4 \pm 1.17^{1^{*}}$ \\
\hline 4 & $12.8 \pm 0.17$ & $12.0 \pm 0.13$ & $11.6 \pm 0.20$ & $94.4 \pm 0.74^{1^{*}}$ & $96.5 \pm 1.30$ \\
\hline
\end{tabular}

${ }^{1}$ is the difference with the first group ${ }^{2}$ the difference with the second group is reliable: ${ }^{*}-\mathrm{p}<0,05 ;{ }^{* *}-\mathrm{p}<0,01$.

Analysis of the reproductive qualities of sows in different combinations of Irish breeds showed that the sows of the $3^{\text {rd }}$ experimental group in terms of the total number of piglets after farrowing were in the lead over the analogs of the second control group by $3.9 \%$ (p
$<0.01)$. In addition, they exceeded the animals of the $1^{\text {st }}$ control group in terms of the number of piglets at 30 days, weight of the nest at 30 days, and survival by $8.1 \%$ (p <0.05), 10.0\% (p <0.05), and 3.6\% (p <0.05), respectively. In the $4^{\text {th }}$ experimental group, the weight of 
the nest at 30 days was greater by $8.1 \%$ ( $\mathrm{p}<0.05$ ), in contrast to the considered indicator of the $1^{\text {st }}$ control group.

According to [9], as a result of heterosis, the prolificacy of Irish sows increased by $0.25-0.50$ in comparison with purebred pigs. In the context of breeds, Landrace sows had a higher level of piglets per litter (by 0.6 heads), number of live births per litter (by 0.5 heads) and average head weight (by $0.13 \mathrm{~kg}$ ) than Yorkshire sows [10]. An increase in the degree of inbreeding and an increase in litter size contributed to an increase in the number of stillborn piglets and individuals with a low weight, which reduces the viability before weaning [11].

In our studies, it was experimentally established that when using interbreeding pigs, the mass of the nest in 30 days increased by $8.1-10.0 \%$ ( $\mathrm{p}<0.05$ ). At the same time, the greatest effect during interbreeding was obtained in the $3^{\text {rd }}$ experimental group in terms of the total number of piglets (13.3 heads), the number of piglets to weaning (12 heads) and their livability (97.4\%). There were no significant differences between the animals of the control groups in terms of reproductive qualities.

\subsection{Pig fattening qualities}

The fattening qualities of pigs of Irish selection of different origins are presented in Table 3.

The analysis of indicators characterizing the fattening qualities of pigs of Irish selection has showed that animals of the Landrace breed have higher average daily gains and high early maturity, exceeding by $3.5 \%$ (p $<0.05)$ and $12.8 \%$ ( $<<0.05)$, respectively, the indicators of the peers of the genotype WP $\times$ WP. Juveniles of genotype LP $\times$ WP were $13.7 \%$ ahead of individuals of the $1^{\text {st }}$ control group in average daily gains $(p<0.05)$. When interbreeding was used in the $3^{\text {rd }}$ and $4^{\text {th }}$ experimental groups, there was a tendency to an increase in the early maturity of young pigs by $3.6 \%$ and $2.9 \%$, respectively, with a difference in relation to the $1^{\text {st }}$ control group.

Table 3. Pig fattening qualities $(n=20)$.

\begin{tabular}{|c|c|c|}
\hline Group & $\begin{array}{c}\text { Age with a live } \\
\text { weight of 100 kg, } \\
\text { days } \pm \text { SD }\end{array}$ & $\begin{array}{c}\text { Live weight gain } \\
\text { (average per day), } \mathbf{g} \pm \\
\text { SD }\end{array}$ \\
\hline 1 & $164.6 \pm 2.70$ & $813.2 \pm 41.90$ \\
\hline 2 & $158.9 \pm 1.49^{1^{*}}$ & $917.0 \pm 16.82^{1^{*}}$ \\
\hline 3 & $158.7 \pm 1.36$ & $911.7 \pm 28.16$ \\
\hline 4 & $159.8 \pm 0.68$ & $924.7 \pm 32.46^{1^{*}}$ \\
\hline
\end{tabular}

${ }^{1}$ the difference with the first group is reliable: ${ }^{*}-\mathrm{p}<0,05$.

In the experiments carried out in [12], no significant differences were found between animals of the Landrace and Large White breeds, as well as between the offspring obtained as a result of crossing these breeds, according to the age of reaching a live weight of $85 \mathrm{~kg}$ by the time of slaughter (174, 175 and 172 days, respectively). Studies [13] in Northern Ireland did not prove the superiority of the Large White and Landrace hybrids over purebred peers in terms of average daily gain and feed conversion.

\subsection{Pig blood indicators}

The results of blood tests of purebred and crossbred Irish pigs are shown in Table 4.

The results of studying blood parameters of pigs at the age of 4 months (table 4 ) showed that young animals of the Large White breed were $10.3 \%$ ( $\mathrm{p}<0.05$ ) superior to animals of the Landrace breed in terms of the calcium content in the blood serum. At the age of 6 months, young animals of the WP $\times$ WP genotype showed a tendency towards an advantage in the studied biochemical parameters of blood over purebred Landrace from $0.9 \%$ to $6.7 \%$.

Table 4. Biochemical parameters of blood of young pigs $(n=4)$.

\begin{tabular}{|c|c|c|c|}
\hline \multirow{2}{*}{ Grgoup } & $\begin{array}{c}\text { Total protein, } \\
\text { g/l } \pm \text { SD }\end{array}$ & $\begin{array}{c}\text { Calcium, } \\
\text { mmol/l } \pm \text { SD }\end{array}$ & $\begin{array}{c}\text { Phosphorus, } \\
\text { mmol/l } \pm \text { SD }\end{array}$ \\
\cline { 2 - 4 } & \multicolumn{3}{|c|}{4 months } \\
\hline 1 & $71.3 \pm 3.67$ & $2.79 \pm 0.076$ & $2.46 \pm 0.055$ \\
\hline 2 & $70.2 \pm 3.20$ & $2.53 \pm 0.017^{1^{*}}$ & $2.39 \pm 0.029$ \\
\hline 3 & $65.3 \pm 2.54$ & $2.51 \pm 0.040^{1^{*}}$ & $2.33 \pm 0.081$ \\
\hline 4 & $79.1 \pm 0.94^{*}$ & $2.96 \pm 0.234$ & $2.64 \pm 0.178$ \\
\hline 1 & $76.5 \pm 4.46$ & $2.51 \pm 0.229$ & $2.85 \pm 0.072$ \\
\hline 2 & $75.8 \pm 3.39$ & $2.38 \pm 0.083$ & $2.67 \pm 0.060$ \\
\hline 3 & $74.6 \pm 1.78$ & $2.43 \pm 0.029$ & $2.85 \pm 0.051$ \\
\hline 4 & $75.2 \pm 2.45$ & $2.35 \pm 0.212$ & $2.80 \pm 0.136$ \\
\hline \multicolumn{4}{|c|}{6 months } \\
\hline
\end{tabular}

Interbreed hybrid juveniles of genotype LP $\times$ WP aged 4 months had a significant advantage over their peers of the $1^{\text {st }}$ control group in terms of total protein content by $10.9 \%$ ( $p<0.05)$, and also had a tendency to higher concentrations of calcium and phosphorus in blood serum by $6.1-17.0 \%$ in contrast to the peers of both control groups. At the age of 6 months, there were no significant intergroup differences in the biochemical parameters of the blood of pigs represented by different genotypes of Irish selection.

In general, the biochemical parameters of the blood of purebred and crossbred young pigs were within the physiological norm.

Young pigs of the $4^{\text {th }}$ experimental group as a whole in comparison with pigs of other genotypes were characterized by a more intensive metabolism. This was confirmed by the obtained results of average daily gains in live weight, which were the maximum in this group.

\subsection{Indicators of muscle and fatty tissue of pigs}

The results of studying physicochemical properties of fatty and muscle tissue of pigs are shown in Table 5. 
The results of the studying the quality of the muscle tissue of pigs in the control and experimental groups (Table 5) demonstrate a higher moisture-binding capacity of meat of Large White animals as a percentage of meat and as a percentage of total moisture by $1.4 \%$ and $5.2 \%$ ( $\mathrm{p}<0.05$ ), respectively, in contrast to pigs of the Landrace breed, which indicates a higher juiciness of meat, which has a greater yield of finished products during technological processing.

Table 5. Technological indicators of pig meat tissue $(n=3)$.

\begin{tabular}{|c|c|c|c|}
\hline \multirow{2}{*}{ Group } & \multicolumn{2}{|c|}{$\begin{array}{c}\text { Moisture binding capacity of } \\
\text { muscle tissue }(\%) \pm \text { SD }\end{array}$} & $\begin{array}{c}\text { Melting point } \\
\text { of fatty tissue } \\
\end{array}$ \\
\cline { 2 - 4 } & meet & $\begin{array}{c}\text { Total } \\
\text { moisture }\end{array}$ & \\
\hline 1 & $56.5 \pm 1.63$ & $80.3 \pm 1.66$ & $30.0 \pm 0.71$ \\
\hline 2 & $55.1 \pm 0.40$ & $75.1 \pm 0.70^{1^{*}}$ & $34.3 \pm 1.08^{1^{*}}$ \\
\hline 3 & $55.4 \pm 1.91$ & $78.7 \pm 3.23$ & $29.0 \pm 2.55$ \\
\hline 4 & $56.6 \pm 1.39$ & $77.5 \pm 1.82$ & $33.0 \pm 0.71^{1^{*}}$ \\
\hline
\end{tabular}

${ }^{1}$ the difference with the first group is reliable: ${ }^{*}-\mathrm{p}<0.05$.

No significant intergroup differences have been found in the moisture-binding capacity of meat of interbreeding hybrids. Compared to analogues of the Landrace breed, animals of both experimental groups tended to have a higher moisture-binding capacity of meat as a percentage of meat by $0.3-1.5 \%$ and as a percentage of total moisture by $2.4-3.6 \%$. Due to the higher moisture-binding capacity, the meat of inter-breed hybrids had higher technological properties and suitability for technological processing.

In [13], Irish hybrid pigs (Landrace x Large White) were characterized by the highest slaughter weight (71.6 $\mathrm{kg}$ ), surpassing purebred individuals by $0.9-1.0 \mathrm{~kg}$. In contrast, Landrace pigs had the highest meat $\mathrm{pH}$ (5.57), while the active acidity of meat from Large White animals and interbreed hybrids was pH 5.52.

Opposite results were reported by [14]. According to the author, the Landrace $\times$ Yorkshire interbreeding crosses had a $\mathrm{pH}$ of 5.81, surpassing their purebred counterparts by 0.19 and 0.22 units. According to [15], there was a significant inverse correlation between the $\mathrm{pH}$ level of meat from Landrace and Yorkshire pigs and the ability to retain moisture in the meat during cooking. At the same time, the authors argued that the differences in the ability to bind moisture were determined not by the breed but by the sex of the animal: the meat of males had a higher $\mathrm{pH}$ and water-holding capacity.

An analysis of the physicochemical properties of the fatty tissue of pigs of Irish selection showed that, in general, the fat of pigs of Irish selection had a rather low melting point, and, consequently, high digestibility. Large White pigs had a $14.3 \%$ lower melting point of fatty tissue ( $p<0.05$ ), in contrast to their peers of the Landrace breed. Crossbreeding helped to reduce the melting point of fatty tissue. Thus, in pigs of the $3^{\text {rd }}$ and $4^{\text {th }}$ experimental groups, the fat melted at a lower temperature by $15.5 \%$ and $3.8 \%$ ( $p<0.05$ ), respectively, than in the control Landrace breed analogues.
In contrast to our data, in China, in studies [14], purebred Landrace was superior to Yorkshire and interbreed analogs in the content of polyunsaturated fatty acids $(28.7 \%$ versus $21.6 \%$ and $17.8 \%)$, whose concentration increase resulted in the decrease of fat melting point.

Thus, young pigs of the Large White breed had a higher water-binding capacity of muscle tissue and a lower melting point of adipose tissue, in contrast to their peers of the Landrace breed. In interbreeding ( \&WP $\times$ LP), a tendency towards a higher moisture-binding capacity of meat was established by $3.6 \%(\mathrm{p}<0.05)$ and a lower melting point of fatty tissue was noted by $15.5 \%$ ( $p<0.05)$ compared with purebred breeding of Landrace pigs.

\section{Conclusion}

Thus, in terms of reproductive qualities, the best combination should be considered the selection of WP $\mathrm{x}$ LP, in which the superiority over purebred breeding of Landrace pigs in the number of all piglets at birth by $3.9 \%(\mathrm{p}<0.01)$ and an advantage over the intrabreed selection of $\$ \mathrm{WP} \times \mathrm{WP}$ by the number of piglets at 30 days, the weight of the nest at 30 days and the survival rate by $8.1 \%(\mathrm{p}<0.05), 10.0 \%(\mathrm{p}<0.05)$ and $3.6 \%(\mathrm{p}$ $<0.05)$, respectively. Young pigs of the Landrace breed surpassed animals of the Large White breed in early maturity by $3.5 \%(\mathrm{p}<0.05)$ and growth rate by $12.8 \%$ (p $<0.05$ ). The combination of breeds according to the \&LP $\times$ WP scheme contributed to an increase in the average daily gain in live weight of the resulting offspring by $13.7 \%$ ( $p<0.05$ ). At the age of 4 months, piglets of the \&LP $\times$ WP genotype had a higher content of total protein in the blood serum by $10.9 \%$ ( $p<0.05$ ), in contrast to animals of the Large White breed, which indicated a higher protein metabolism in their body. The muscle tissue of Large White pigs was characterized by a $5.2 \%$ ( $\mathrm{p}<0.05)$ higher moisture binding capacity in relation to Landrace pigs. Crossbred young animals occupied an intermediate position in terms of moisture binding capacity compared to the original parental forms. The melting point of fatty tissue was lower in Large White pigs by $14.3 \%(\mathrm{p}<0.05)$. The fatty tissue of LP $\times$ WP hybrids had a $10.0 \%(\mathrm{p}<0.05)$ higher melting point, in contrast to Large White pigs.

\section{References}

1. S. Burtseva, I. Pushkarev, A. Trebukhov, N. Vladimirov, L. Tkachenko, I. Klimenok IOP conference series: Earth and environmental science, 341 (2019)

2. O. Vidal, J. Noguera, M. Amills, L. Varona, M. Gil, N. Jiménez Journal of animal science, 83, 293-300 (2005).

3. R. Reish, B. Zuhaili, J. Bergmann, P. Aflaki, T. Koyama, F. Hackl, E. Waisbren Wound Repair Regen, 17, 806-816, (2009).

4. J. McGlone Animals (Basel), 3, 401-415 (2013). 
5. Z. Perevoiko, V. Kosilov Izvestia Orenburg State Agrarian University, 6, 161-163 (2014).

6. S. Grikshas, G. Funikov, N. Gubanova, P. Korenevskaya Achievements of Science and Technology of AICis, 4, 62-63 (2011).

7. S. Burtseva, L. Pautova Bulletin of Altai state agricultural university, 144, 102-106 (2016).

8. I. Gordon Reproductive technologies in farm animals. (Dublin: CABI, 2017).

9. P. Lawlor, P. Lynch Irish veterinary journal, 60, 359-366 (2007).

10. W. Tantasuparuk, N. Lundeheim, A. Dalin, A. Kunavongkrit, S. Einarsson, Theriogenology, 54, 481-496 (2000).

11. R. Johnson, M. Nielsen, D. Casey Journal of Animal Science, 77, 541-557 (1999).

12. W. Smith, G. Pearson, D. Garrick New Zealand journal of agricultural research, 31, 421-430 (1988).

13. M. McCann, V. Beattie, D. Watt, B. Moss The Irish journal of agricultural and food research, 47, 171-185 (2008).

14. J. Zhang, J. Chai, Z. Luo, H. He, L. Chen, X. Liu, Q. Zhou Animal science journal, 89, 202-210 (2017)

15. Y. Li, M. Cabling, H. Kang, T. Kim, S. Yeom, Y. Sohn, S. Kim, K. Nam, K. Seo AsianAustralasian journal of animal sciences, 26, 905910 (2013). 